\title{
Black/White Biracial Identity: The Influence of Colorblindness and the Racialization of Poor Black Americans
}

\author{
Kathleen Odell Korgen ${ }^{1}$
}

This article focuses on the influence of colorblindness, the interaction of class and culture, and the racialization of poor Black culture on the racial identity of Biracial Americans with both a Black and a White parent. In doing so, it makes the following points: 1) Despite the fact that almost all Biracial persons experience racism (particularly during adolescence), the ideology of colorblindness promotes a non-racial or "honorary white" racial identity among middle and upper-middle class Biracial persons who live in predominantly white settings, 2) Many middle and upper-middle class Biracial persons have more in common with their White neighbors than with poor Black Americans. 3) The common stereotype of "true" Blackness connects it to the culture of poor, marginalized Black Americans. These points are conceptually distinct, yet all promote the distance many middle- and upper-class Biracial Americans feel from a Black racial identity. [Article copies available for a fee from The Transformative Studies Institute. E-mail address: journal@transformativestudies.org Website: http://www.transformativestudies.org (c2009 by The Transformative Studies Institute. All rights reserved.]

KEYWORDS: Ideology of Colorblindness, Class, Culture, Racialization, Stereotype, Racial Identity, "Honorary White”.

How do persons with both a Black and a White parent racially identify in a society in which race is no longer supposed to matter? In a society in which Blackness is tied to poor Black culture, how do they identify if

\footnotetext{
${ }^{1}$ Kathleen Odell Korgen is Professor of Sociology at William Paterson University in Wayne, New Jersey. Her published works on race relations and racial identity includes Crossing the Racial Divide: Close Friendships Between Black and White Americans (Praeger 2002) and From Black to Biracial (Praeger 1998, 1999). She is the co-author (with Jonathan White) of The Engaged Sociologist: Connecting the Classroom to the Community (Pine Forge 2007, 2008). Address correspondence to: Dr. Kathleen Odell Korgen, William Paterson University, Raubinger Hall, Room \#420, 300 Pompton Road, Wayne, NJ 07470 USA; tel: +(973) 720-3563; e-mail: korgenk@wpunj.edu.
} 